Jabłoński B., Kuczowic J., Microeconomic and macroeconomic determinants of the dividend policy in companies quoted at Warsaw Stock Exchange - research results, „Ekonomia i Prawo. Economics and Law", Polszakiewicz B., Boehlke J. (ed.), Vol. 14, No. 4/2015, pp. 443-457. DOI: http:// dx.doi.org/10.12775/EiP.2015.029.

\author{
BARTŁOMIEJ JABŁOŃSKI*, JACEK KUCZOWIC
}

\title{
MICROECONOMIC AND MACROECONOMIC DETERMINANTS OF THE DIVIDEND POLICY IN COMPANIES QUOTED AT WARSAW STOCK EXCHANGE - RESEARCH RESULTS ${ }^{\diamond}$
}

\section{SUMMARY}

The article presents results of research devoted to determinants of the dividend policy of companies quoted at Warsaw Stock Exchange in Warsaw. The presentation of the authors' analyses is preceded by a review of studies described in the literature, carried out in scientific centres in Poland and abroad, in the breakdown into studies referring to two groups of factors: the microeconomic and the macroeconomic ones.

The studies presented covered an analysis of correlation between the value of the paid-out dividend and selected parameters which describe the financial and property-related standing of companies, as well as macroeconomic factors. The research based on data from the years 2002-2013. It was summed up in a comparative analysis of microeconomic and macroeconomic determinants of dividend-related decisions of companies.

Keywords: dividend policy; cash flow; profit; CPI inflation rate; PMI factor JEL Classification: D00; D24; E31; G35

" Bartłomiej Jabłoński, Katowice University of Economics, Faculty of Finance and Insurance, Department of Investment and Real Estate, ul. 1 Maja 50, 40-287 Katowice, Poland, phone: +48 3225775 10, e-mail:bartlomiej.jablonski@ue.katowice.pl (corresponding author).

** Jacek Kuczowic, Katowice University of Economics, Faculty of Finance and Insurance, Department of Investment and Real Estate, ul. 1 Maja 50, 40-287 Katowice, Poland, phone: +48 3225775 10, e-mail:jacek.kuczowic@ue.katowice.pl.

$\checkmark$ The article was funded from the Statutory Research Programme of University of Economics in Katowice. 


\section{INTRODUCTION}

The subject of determinants of the dividend policy, as well as changes occurring in the form, frequency or even the value of the dividend payout, has been widely described in the foreign and Polish literature (e.g. J.H. von Eije, W.L. Meggison, S.P. Ferris, N. Sen, H. Pei Yui, H. DeAngelo, L. DeAngelo, D. Skinner, A. Damodaran, M. Jagannathan, C.P. Stephens, M.S. Weisbach, E.F. Fama, K.R. French, G. Grullon, D.L. Ikenberry, A. Brav, J.R. Graham, C.R. Harvey, R. Michaely, M. Sierpińska, B. Horbaczewska, R. Tuzimek, A. Szablewski, M. Kowerski, T. Słoński, B. Jabłoński, J. Kuczowic) ${ }^{1}$.

A series of parameters which determine the possibility of the dividend payout is ascribed to a group of microeconomic or macroeconomic factors. These factors - in a way - influence the realistic options of profit transfer to shareholders. Very often, however, studies disregard groups of other factors which might have their impact on the dividend payout. They can com-

${ }^{1}$ J.H. von Eije, W.L. Megginson, Dividends and Share Repurchases in the European Union, "Journal of Financial Economics", Vol. 89, No. 2/2008, pp. 347-374; J.H. von Eije, W.L. Megginson, Dividend Policy in the European Union, "SSRN Electronic Journal", Vol. 2006, pp. 1-41; S.P. Ferris, N. Sen, H. Pei Yui, Are Ferwer Firms Paying More Dividends?, "Journal of Multinational Financial Management”, Vol. 16, No. 4/2006, pp. 333-362; H. DeAngelo, L. DeAngelo, D. Skinner, Special Dividends and The Evolution of Dividend Signaling, "Journal of Financial Economics", Vol. 57, No. 3/2000, pp. 309-354; A. Damodaran, Analyzing Cash Returned to Stockholders, http://pages.stern.nyu.edu/ adamodar/pdfiles/acf2E/Chap11. pdf (15.02.2015); M. Jagannathan, C.P. Stephens, M.S. Weisbach, Financial Flexibility and The Choice between Dividends and Stock Repurchases, "Journal of Financial Economics", Vol. 57, No. 3/2000, pp. 355-384; E.F. Fama, K.F. French, Disappearing Dividends: Changing Firm Characteristics or Lower Propensity to Pay?, "Journal of Financial Economics", Vol. 60, No. 1/2001, pp. 3-43; G. Grullon, D.L. Ikenberry, What Do We Know About Stock Repurchase?, "Journal of Applied Corporate Finance", Vol. 13, No. 1/2000, pp. 31-51; A. Brav, J.R. Graham, C.R. Harvey, R. Michaely, Payout Policy in The 21st Century, "Journal of Financial Economics", Vol. 77, No. 3/2005, pp. 483-527; M. Sierpińska, Polityka dywidend w spótkach kapitatowych, PWN, Warszawa-Kraków 1999; B. Horbaczewska, Wyptaty dla akcjonariuszy a wycena akcji na rynku kapitatowym, CeDeWu, Warszawa 2012; R. Tuzimek, Decyzje finansowe w spótkach gietdowych a wartośc akcji, Szkoła Główna Handlowa. Oficyna Wydawnicza, Warszawa 2013; A. Szablewski, R. Tuzimek, Wycena i zarzadzanie wartościa firmy, Poltext, Warszawa 2006; M. Kowerski, Ekonomiczne uwarunkowania decyzji o wyptatach dywidend przez spótki publiczne, Konsorcjum Akademickie, Kraków 2011; T. Słoński, Analiza wptywu wspomaganego dtugiem wykupu akcji (LBO) na wartość spótki, Wydawnictwo Uniwersytetu Ekonomicznego we Wrocławiu, Wrocław 2012; B. Jabłoński, J. Kuczowic, The Issue of Dividend Policies of Companies Listed on War-saw Stock Exchange - Results of the Research, [in:] O. Deev, V. Kajurová, J. Krajíček (eds.), European Financial Systems 2014, Proceedings of the 11th International Scientific Conference, Brno 2014. pp. 272-279. 
prise behavioural or market-related factors. The objective of this article is to compare the effect of both groups of factors on investment-related decisions of companies quoted at Warsaw Stock Exchange.

The article presents results of research which aims to verify the hypothesis: H1: The correlation between macroeconomic factors and the value of the dividend paid out by companies is higher than the respective correlation of the microeconomic factors. Microeconomic factors for which the hypothesis was verified are financial parameters which describe the company's activity and assets: operating income, net profit, cash flow, investment cash flow, cash, assets, fixed capital, equity capital, Return on Assets, Return on Equity. The analyzed macroeconomic factors are: GDP growth factor, CPI inflation rate, PMI factor.

The analysis covers companies which are classified as belonging to the WIG20, mWIG40 and sWIG80 indexes at Warsaw Stock Exchange in the period 2002-2013, whereas financial companies were disregarded.

The research was conducted in the following stages:

1. Stage one - defining and selection of dividend companies.

2. Stage two - analysis of the correlation between the amount of the paidout dividend with the parameters specified in the hypothesis, describing the companies' operations. The research covered relations between the dividends paid out in the year " $t$ " with data from a financial statement from the year " $t-1$ " and data from the financial statement for the year " $t$ ".

3. Stage three - analysis of the correlation between the paid out dividend and the macroeconomic factors specified in the hypothesis. The factors adopted for the sake of the analysis derived from various periods of the analyzed year (details are described in item 3). The correlation was examined with the application of Pearson's linear correlation coefficient.

4. Stage four - comparative analysis of the calculated correlation coefficients.

\section{DIVIDEND POLICY FROM THE PERSPECTIVE OF FINANCIAL PARAMETERS OF A COMPANY — RESULTS OF POLISH AND INTERNATIONAL STUDIES}

The level of a company's profit and the level of the dividend remain in close relation with the capital structure and the average cost of the total capital. The profit reinvestment results in the increase of equity capitals, 
which considering the unchanged level of the external capital causes an increase of the share of the former in the capital structure ${ }^{2}$.

The studies conducted (J. Lintner) ${ }^{3}$ imply that the higher the profit generated by a company, the better chance for a dividend to be paid out. E.F. Fama and K.F. French conducted studies which confirm that the dividend payouts depend on - without limitations - the profitability of the company, as well as its retained profit ${ }^{4}$.

Retained profit is a kind of a catalyst for dividends in a situation where a company has generated a lower financial result or reports a demand for cash due to investment implementation. Despite the fact that dividends can be paid out at a lower level, the regularity of their payout will not be unsettled. It is particularly important for relatively young entities, which is confirmed by the studies conducted by H.DeAngelo, L. DeAngelo and R.M.Stulz ${ }^{5}$. The analysis of the literature also implies that changes in the paid-out dividends are connected with long-term fluctuations of profits, whereas shortterm fluctuations of financial results, if any, are disregarded when determining the value of the cash transfer to shareholders. A. Brav, J.R. Graham, C.R. Harley and R. Michaely ${ }^{6}$ stated that from the point of view of financial results dividends are paid out by entities which generate moderately stable profits.

Cash accessibility, resulting from - among other factors - the profit generated by the entity, tell of the issuer's cash-related ability to transfer cash to shareholders. Entities which exhibit a high level of accumulated profit pay out dividends, despite the fact that the current condition of cash does not allow it. They then finance the dividend payouts from the external capital or a new emission of shares ${ }^{7}$.

Research results suggesting that dividend payouts based on cash flow exhibit a higher level of stability are also encountered ${ }^{8}$. The studies carried out

${ }^{2}$ E.M. Wrońska, Polityka dywidend, [in:] P. Karpuś, (ed.), Zarzqdzanie finansami przedsiębiorstw, Wydawnictwo Uniwersytetu Marii Curie-Skłodowskiej, Lublin 2006, pp. 387-419.

${ }^{3}$ J. Lintner, Distribution of Incomes of Corporations Among Dividends, Retained Earnings, and Taxes, “The American Economic Review”, Vol. 46, No. 2/1956, pp. 97-113.

${ }^{4}$ E.F. Fama, K.F. French, op. cit, pp. 3-43.

5 See more: H. DeAngelo, L. DeAngelo, R.M. Stulz, Dividend policy and the earned/contributed capital mix: a test of the life-cycle theory, "Journal of Financial Economics", Vol. 81, No. 2/2006, pp. 227-254.

${ }^{6}$ A. Brav, J.R. Graham, C.R. Harvey, R. Michaely, op. cit., pp. 483-527.

${ }^{7}$ Often such a situation happens in companies quoted on the American market, especially when the issuer does not wish to lose the status of a dividend company.

8 E.F.Brigham, J.F. Houston, Podstawy zarzadzania finansami, PWE, Warszawa 2005, pp. 210-211. 
by J.B. Chay and J. Suh ${ }^{9}$ indicate that the variability of cash flow has its effect on the dividend payouts. Companies which exhibit a high level of variability of cash flow pay out lower dividends. Furthermore, the research carried out by M. Jagannathan, C.P. Stephens and M.S. Weisbach ${ }^{10}$ suggests that companies which generate stable cash flow from their operating activity pay out dividends more frequently. Furthermore, W. Guay and J. Harford ${ }^{11}$ claim on the basis of their studies that companies which pay out dividends are characterized by stable cash flow. Also a high level of variability of cash flow can cause fear of the management boards concerning the future stability of the company's results, and in doing so it hinders dividend payouts. The issue of cash flow was also taken into account in the models of the analysis of the dividend policy. A Szablewski ${ }^{12}$ proposed taking into account - among other factors - FCFE in the decisions whether to pay out or to stop paying out dividends.

Companies' investments find their reflection in the cash flow account specifically in the investment cash flow. Therefore, an analysis of the ability to pay out dividends on the basis of the cash flow account can be carried out specifying it as a general one, that is taking into account cash flow from operating, investment and financial activity, and on the basis of the investmentrelated part of the cash flow account, that is investment cash flow.

Companies which implement investment projects try to finance them firstly from the generated profit in compliance with the theory of the financing sources hierarchy ${ }^{13}$. That is why all investments of companies which engage internal capital will have a negative effect on the possibility of paying out dividends. The research results available in the literature pertaining to the dividend payouts in the relation to the investment capabilities cover an analysis of the dynamics of assets, changes in the sales revenues or the relation of the market value to the total value of assets or company's own capi$\operatorname{tals}^{14}$.

9 J.B. Chay, J. Suh, Payout Policy and Cash-Flow Uncertainty, "Journal of Financial Economics", Vol. 93, No. 1/2009, pp. 88-107.

${ }^{10}$ M. Jagannathan, C.P. Stephens, M.S. Weisbach, op. cit., pp. 355-384.

${ }^{11}$ W. Guay, J. Harford, The Cash-flow permanence and information content of dividend increases versus repurchases, "Journal of Financial Economics, Vol. 57, No. 3/2000, pp. 385-415.

12 A. Szablewski, Zarzqdzanie wartościa firmy. Istota i kierunki ewolucji, [in:] A. Sza-blewski (ed.), Strategie wzrostu wartości firmy. Studium przypadków, Poltext, Warszawa 2000, p. 22.

${ }^{13}$ See more: L. Bulan, Y. Zhipeng, The Pecking Order of Financing in the Firm's Life Cycle, http://69.175.2.130/ finman/Orlando/Papers/ThePeckingOrderofFinancinginthe FirmsLifeCyclen2n.pdf (30.03.2015).

${ }^{14}$ M. Kowerski, op. cit., p. 254. 
Entities which implement profitable investment projects try to limit dividend payouts for the benefit of development and growth of the value of the entity. Therefore, paying out too high dividends by an entity may hamper the implementation of essential investment projects, which in turn in a long run may lead to the entity's bankruptcy ${ }^{15}$.

Companies which have a considerable share of fixed assets in the overall assets structure are able to benefit from the external capital to a greater extent. In a situation where a company does not hold any free cash, it can secure the debt with its assets, and thus pay out the dividend anyway. A high share of the debt in financing an entity's operations, on the other hand, may signal its future high profitability, which will reduce the role of the dividend as a carrier of such information. It happens when fluctuations in the dividend payouts (increase of the paid-out dividend with respect to shares) are interpreted as a signal of improvement of the company's profitability.

D. Denis and I. Osobov on the basis of their research concluded that companies whose level of their own capital grows systematically, are more willing to share the generated earnings with their shareholders. It is important, however, that the company's own capital grows systematically by generating and accumulating profits ${ }^{16}$. Other causes of changes in the company's own capital due to the dividend payouts are not necessarily interpreted positively by investors. The emission of shares in order to finance the dividend payout is often recognized as an inappropriate decision, especially if the investors covering such an emission count on effective use of the funds transferred to the company ${ }^{17}$.

\section{DIVIDEND POLICY FROM THE POINT OF VIEW OF A COMPANY'S ENVIRONMENT - RESULTS OF POLISH AND INTERNATIONAL STUDIES}

Authors of research devoted to the dividend policy recognize not only microeconomic factors as its determinants, but also macroeconomic ones, which have a significant effect on proper operation of companies. The latter comprise inflation (expressed by the CPI factor), as a measurement of an av-

15 See more: P.J. Szczepankowski, Finanse przedsiębiorstwa. Teoria i praktyka, Wydawnictwo WSPiZ, Warszawa 1999, p. 122 and next.

${ }_{16}$ M. Kowerski, op. cit., p. 173; 177.

17 See more: A. Cwynar, W. Cwynar, Kreowanie wartości spótki poprzez dtugoterminowe decyzje finansowe, Polska Akademia Rachunkowości, Wydawnictwo Wyższej Szkoły In-formatyki i Zarządzania, Warszawa-Rzeszów 2007. 
erage growth of goods and services in the economy, and the gross domestic product (GDP). Causes of the occurrence of inflation in the economy comprise issuing too much paper money on the market $\left(\mathrm{H}\right.$. Hazlitt ${ }^{18}$ or a universal cash balance, consumer expenses or monetary expansion occurring via credit markets (M. Skousen) ${ }^{19}$.

Companies which operate in the conditions of high inflation ${ }^{20}$ not only decrease the level of the dividend, but even cease to pay out the dividend to shareholders. Companies try to reinvest their generated profits fast enough to secure that only the smallest share possible of the generated profit loses its actual value. Additionally, the actual value of the paid-out dividend rapidly decreases since the moment of making a decision about its payout. In this period companies increase their engagement in the assets necessary to continue their operating activities ${ }^{21}$.

Another factor believed to influence the possibility of the dividend payouts by a company is the gross domestic product, which is one of the most fundamental measurements of the national income. It describes the aggregated value of final goods and services generated during a year within the area of one country. The study conducted by W. Dębski and I. Bujnowicz ${ }^{22}$ for the Polish market for the period 1994-2005 implies that there is a strong interdependence between the variables which describe the development of the financial market and the variables which describe the economic growth. The research carried out at Warsaw Stock Exchange for the period 19962009 by M. Kowerski ${ }^{23}$, on the other hand, suggests that the economic situation measured by the dynamics of changes of GDP in the year $t-1$ has a positive effect on decisions to pay out dividends in the year $t$. In particular it refers to companies which enjoy a good economic and financial standing.

Yet another group of factors emerges in the research devoted to determinants of the dividend payout - psychological factors. They comprise economic moods of entrepreneurs, which translate to a significant extent not only into decisions on the distribution of the generated profit, but also on its further engagement. They are calculated with the application of various meth-

${ }_{18}$ H. Hazlitt, Inflacja, Wróg publiczny nr 1, Fijorr Publishing, Warszawa 2007, p. 61.

19 M. Skousen, Struktura produkcji. Gietda, kapitat, konsumpcja, Fijorr Publishing, Warszawa 2011, p. 318 and next.

${ }^{20}$ High inflation level is understood as a two-digit increase of prices in a year's scale.

${ }^{21}$ See more: M. Skousen, op. cit.; H. Hazlitt, op. cit.

${ }^{22}$ W. Dębski, I. Bujnowicz, Model wspótzależności rozwoju systemu finansowego i wzrostu gospodarczego w Polsce, "Studia i Prace Wydziału Nauk Ekonomicznych i Zarzadzania Uniwersytetu Szczecińskiego”, Vol. 9/2008, pp. 9-20, [quoted after:] M. Kowerski, op. cit., p. 126.

${ }_{23}$ M. Kowerski, op. cit., pp. 129-131; 271-279. 
ods and measurements. One can point out synthetic factors calculated by e.g. the European Commission, the Research Institute for Economic Development at Warsaw School of Economics or the PMI index ${ }^{24}$. PMI is calculated on the basis of a monthly survey conducted among managerial staff in over $300 \mathrm{com}$ panies. The survey evaluates fluctuations of orders, production, employment, speed of supplies and stock. The reading above 50 stands for an improvement in comparison to the previous period, whereas the reading below this value stands for the deterioration of the situation.

The research carried out by $\mathrm{M}$. Kowerski ${ }^{25}$ implies that the better the economic moods in June in a given year, the higher probability of the dividend payouts in the same year. The results of this research can be recognized as quite surprising from the point of view of the sequence of events as economic moods of entrepreneurs which influence their decisions in the base year will translate into the results of the entities in the future. Decisions on the dividend payout are made most of all on the basis of historical results. If the managers optimistically decide to pay out the dividend, not necessarily in connection with the condition of the company's finances and the actual possibilities of the cash transfer to shareholders, a trap consisting in paying out too high a dividend on the basis of individual sentiments of a person is well visible.

\section{CORRELATION BETWEEN THE DIVIDEND OF COMPANIES QUOTED AT WARSAW STOCK EXCHANGE AND SELECTED OPERATING PARAME- TERS AND MACROECONOMIC FACTORS - RESEARCH RESULTS}

The research presented herein covered 48 companies quoted at Warsaw Stock Exchange, recognized as dividend companies for the purposes of the analysis $^{26} .8$ of them were quoted in the WIG20 index, 15 in the mWIG40 index and 25 in the sWIG80 index. In the analyzed period, these companies paid out the dividend 7.9 times on average, whereas this mean in companies belonging to individual indexes slightly differed (7.9, 7.2 and 8.3, respective-

\footnotetext{
${ }^{24}$ PMI - or Purchasing Managers Index of the Polish industrial sector, prepared by the research entity Markit Economics.

${ }^{25}$ M. Kowerski, op. cit., p. 308.

${ }^{26}$ The number of companies quoted at Warsaw Stock Exchange which pay out the dividend regularly is relatively small. Companies which in the analysed 12-months' period paid out the dividend at least 5 times were qualified to participate in the study, which allows to determine the correlation with Pearson's correlation coefficient in a reliable way.
} 
ly). 11 examined companies paid out the dividend at least 10 times in the analyzed period.

Contrary to the relations between the paid out dividend and the financial parameters of a company's operation, extensively described in the literature, it is really difficult to find such relations among the companies quoted at Warsaw Stock Exchange. None of the parameters of the companies' operations selected to the analysis exhibited a significant correlation with the paid-out dividend, despite the fact that the parameters commonly recognized as determinants of the dividend policy were also taken into account. Correlation coefficients calculated for individual companies very rarely reached the level which could be recognized as statistically significant.

Table 1. Medians of Pearson's correlation coefficients in the breakdown into indexes - correlation between the value of the paid-out dividend and the parameters of the operations of the examined companies in the year for which the dividend was paid out $(t-1)$ and the year of the dividend payout $(t)$.

\begin{tabular}{|c|c|c|}
\hline OPERATING PARAMETER & YEAR $t-1$ & YEAR $t$ \\
\hline Operating income & 0.287 & -0.202 \\
\hline Net profit & 0.219 & -0.306 \\
\hline Cash flow & -0.041 & -0.130 \\
\hline Investment cash flow & 0.100 & 0.178 \\
\hline Assets & 0.462 & 0.133 \\
\hline Fixed capital & 0.392 & 0.017 \\
\hline Equity capital & 0.338 & 0.179 \\
\hline Cash & 0.134 & -0.054 \\
\hline ROA & -0.015 & -0.406 \\
\hline ROE & -0.061 & -0.400 \\
\hline
\end{tabular}

Source: Own preparation.

Table 1 presents medians of coefficients of the correlation between the dividend and the analyzed parameters. Two groups of coefficients were calculated, referring to the parameters of the company's operation in the year preceding the dividend payout (for which the dividend was paid out) and parameters of its operation in the subsequent year. The first group of coefficients due to the time shift of the data points out to a one-sided dependence of the dividend on the generated results and the assets held. The other group points out to potential two-sided relations - on one hand relations between the annual parameters of the company's operation and the paid-out dividend, 
and on the other hand dependence of the dividend on the financial results and the value of the assets during the year in which the dividend-related decisions are made (usually by June of that year).

Theoretically, the correlation between the dividend on one hand and the financial results and value of the assets during the previous year on the other should be positive. Indeed, it is; however, the level of this interdependence is very low. Nevertheless, the highest level of correlation refers not to financial results (net profit, operating income), but to the value of the company's property (assets, fixed capital and equity capital). Medians of coefficients of the correlation between the value of the paid-out dividend and the property-describing parameters exceed 0.3. In the conducted research, the correlation between the dividend with total cash flow, frequently reported in the literature, was not observed at all. On the contrary, the median of the coefficient is negative, whereas its value is close to zero. The median of the coefficient of the correlation between the dividend and investment cash flow is equally low, although theoretically investment expenses should significantly reduce the possibility of dividend payouts. Similarly, no significant correlation between the dividend and the achieved profitability (ROE and ROA) was observed.

The analysis of the median of the correlation coefficients gives results similar to the ones of the analysis of individual correlation coefficients for individual companies. In $39.9 \%$ of companies a statistically significant correlation between the dividend and the value of the fixed capital and the equity capital was observed. A statistically significant correlation of the dividend occurred also in $33.3 \%$ of companies in terms of the net profit, $31.3 \%$ of companies in terms of the assets and in $27.1 \%$ of companies in terms of the operating income. The remaining parameters were statistically significantly correlated with the dividend only in several companies. Disregarding the obvious relation between the dividend and the profit from which it is paid out, it can be assumed that the value of the dividend in the companies depends predominantly on the value of the company's property (capital).

Correlation between the dividend and the effects of the company's operation in the year of the dividend payout practically does not occur at all. Medians of relevant correlation coefficients are mostly negative (which is justified, because the increase of the dividend limits the company's potential), but very low.

The observed relatively low correlation between the dividend policy on one hand and the achieved results and economic standing of the company on the other induces to search for its other determinants. Within the scheme of the study the correlations of the paid-out dividend with the indicators 
of the economic situation in the country were calculated. The study took into account the growth rate of GDP from January of the year of the dividend payout and the PMI factor from December of the year for which the dividend was paid out, from January of the year of the dividend payout and from May of the same year. The GDP growth rate reflects the actual results of the economy, and the PMI factor reflects entrepreneurs' moods. In the latter case, various periods in which initial or final dividend-related decisions are made were taken into consideration. Furthermore, the relation between the dividend-related decisions and the inflation rate in the period of making the initial (January) and final (May) decisions was examined.

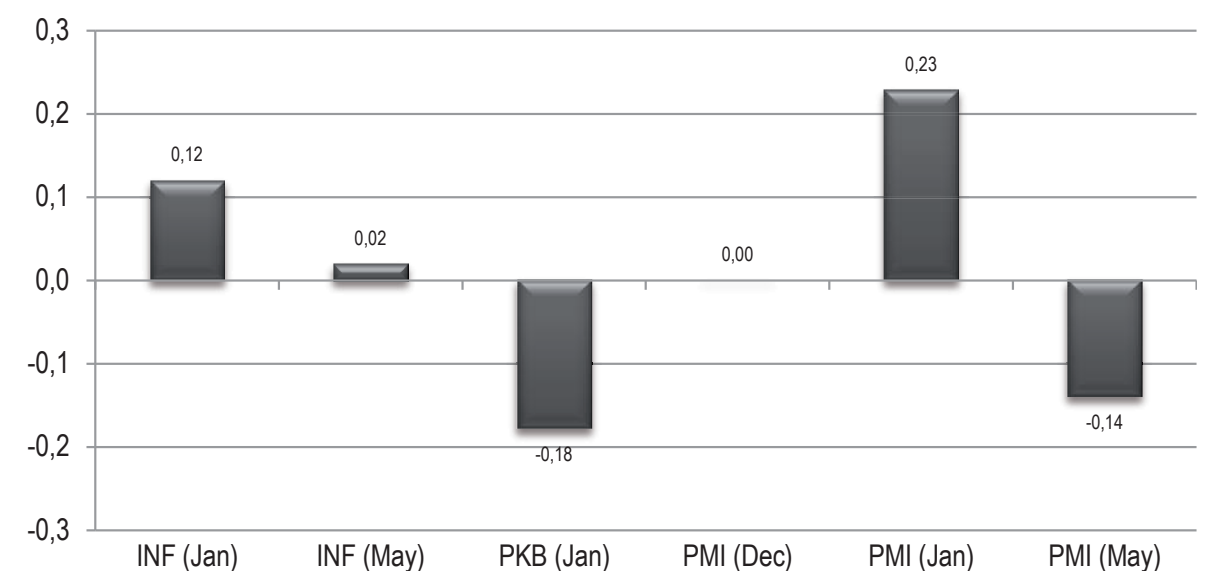

Figure 1. Pearson's correlation coefficient (median) - correlation between the dividend paid out by the examined companies and the selected macroeconomic factors and PMI

Source: Own preparation.

Dividend-related decisions are not consistent with the condition of the economy expressed by the GDP growth rate and the inflation rate, nor with entrepreneurs' moods (figure 1). The calculations point out to the lack of correlation between the value of the paid-out dividend with GDP (median of the correlation coefficient -0.177). The negative median of the coefficient of the correlation between the dividend and GDP can point out to limiting the paid-out dividend as the economic situation improves, which is justified in economic terms. This is not confirmed, however, by a low level of correlation of the value of the dividend with the moods in the economy, expressed by the PMI factor. Such a correlation can be identified only with reference to the moods in January (median of the correlation coefficient is 0.228). It is then that management boards provide proposals of dividend-related decisions and the way in which the nearest future is perceived has a certain im- 
pact on them. Also, the inflation level does not determine the dividend-related decisions in any way. Similarly to the PMI factor, the level of inflation has its impact, if any, on dividend-related decisions at the beginning of the year. A minor level of inflation fluctuations in the analyzed period does not allow, however, to draw significant conclusions in this respect.

A slightly different image of relations between the dividend policy of companies and macroeconomic changes is offered by the analysis of correlation coefficients for individual companies. The fundamental conclusions are similar - a statistically significant correlation with any macroeconomic factors and PMI occurred only in 16 cases (in 288 correlation coefficients calculated). What is characteristic, however, nearly a half of these cases ( 7 coefficients) referred to the growth of GDP. Assuming that the dividend-related decisions are significantly influenced by the way the future is perceived, it can indicate that the GDP growth factor is a better reflection of the moods of decision makers than PMI is.

Table 2. Number of companies in which there occurs a statistically significant positive correlation of the paid-out dividend and selected parameters of the operations of the examined companies in the year for which the dividend was paid out $(t-1)$ and selected economic factors.

\begin{tabular}{|c|c|c|}
\hline \multirow{2}{*}{ Operating PARAMETER } & \multicolumn{2}{|c|}{ POSITIVE CORRELATION } \\
\cline { 2 - 3 } & NUMBER OF COMPANIES & \% OF COMPANIES \\
\hline Net profit & 16 & 33.3 \\
\hline Fixed capital & 19 & 39.6 \\
\hline Equity capital & 19 & 39.6 \\
\hline GDP growth (Jan.) & 4 & 8.3 \\
\hline Inflation (Jan.) & 2 & 4.2 \\
\hline PMI (Dec.) & 1 & 2.1 \\
\hline
\end{tabular}

Source: Own preparation.

Table 2 contains a comparison of the number of companies where a statistically significant correlation between the dividend policy (expressed by changes in the value of the paid-out dividend) and the examined microeconomic and macroeconomic factors was observed. Three factors were selected in each group of the factors which were connected with the largest number of statistically significant correlation coefficients. The list was limited to cases in which the correlation coefficient was positive, because negative coefficients were extremely rare. The list presented is quite explicit. The effect of macroeconomic factors on dividend-related decisions is symbolic. These factors probably influence the moods of the stock exchange market in a non-uni- 
form way; however, they do not translate in any observable way into the dividend policy. Consequently, the initially assumed hypothesis should be rejected.

\section{CONCLUSIONS}

The review of determinants of the dividend policy on the basis of the Polish and international literature indicates that the conditions for the dividend payouts should be looked for in numerous areas of the company's operation, as well as in its surrounding environment. The results of the research carried out in various research centres are frequently contradictory and do not offer a consistent image of the relations occurring in the domain of a company's management under discussion. The selected results of studies carried out by the authors on the basis of selected dividend companies presented in this article do not allow to confirm the significance of any of the factors traditionally recognized as the determinants of the dividend policy. It refers to the parameters which describe the results of the company's operation and its potential, as well as the macroeconomic factors. Among the former ones, only changes in the level of capital can be recognized as partially correlated with the fluctuations of the levels of the dividend.

The comparison of the effect of microeconomic and macroeconomic factors on dividend-related decisions of companies presented herein points out to an explicit advantage of the former ones. It does not mean, however, that the value of the dividend directly depends on the financial and property-related parameters of the company. The research indicates that the relations in the area of the dividend policy are more complex and determinants described in a dynamic way should be looked for. Nevertheless, perhaps the main determinants of the dividend policy should be looked for in the behavioural domain, ownership relations, and partly also in the political situation. These are, at the same time, further areas of the search of determinants of the dividend policy conducted by the authors.

\section{BIBLIOGRAPHY}

Brav A., Graham J.R., Harvey C.R., Michaely R., Payout Policy in The 21 $1^{\text {st }}$ Century, "Journal of Financial Economics", Vol. 77, No. 3/2005, http://dx.doi. org/10.1016/j.jineco.2004.07.004.

Brigham E.F., Houston J.F., Podstawy zarzadzania finansami, PWE, Warszawa 2005. 
Bulan L., Zhipeng Y., The Pecking Order of Financing in the Firm's Life Cycle, http://69.175.2.130/ finman/Orlando/Papers/ThePeckingOrderofFinancingintheFirmsLifeCyclen2n.pdf (30.03.2015).

Chay J.B., Suh J., Payout Policy and Cash-Flow Uncertainty, "Journal of Financial Economics", Vol. 93, No. 1/2009, http://dx.doi.org/10.1016/j.jfineco.2008.12.001.

Cwynar A., Cwynar W., Kreowanie wartości spótki poprzez dtugoterminowe decyzje finansowe, Polska Akademia Rachunkowości, Wydawnictwo Wyższej Szkoły Informatyki i Zarządzania, Warszawa-Rzeszów 2007.

Damodaran A., Analyzing Cash Returned to Stockholders, http://pages.stern.nyu. edu/ adamodar/pdfiles/acf2E/Chap11.pdf (15.02.2015).

DeAngelo H., DeAngelo L., Skinner D., Special Dividends and The Evolution of Dividend Signaling, "Journal of Financial Economics", Vol. 57, No. 3/2000, http:// dx.doi.org/10.1016/s0304-405x(00)00060-x.

DeAngelo H., DeAngelo L., Stulz R.M., Dividend policy and the earned/contributed capital mix: a test of the life-cycle theory, "Journal of Financial Economics", Vol. 81, No. 2/2006, http://dx.doi.org/10.1016/j.jfineco.2005.07.005.

Dębski W., Bujnowicz I., Model wspótzależności rozwoju systemu finansowego i wzrostu gospodarczego w Polsce, "Studia i Prace Wydziału Nauk Ekonomicznych i Zarzadzania Uniwersytetu Szczecińskiego”, Vol. 9/2008.

Fama E.F., French K.R., Disappearing Dividends: Changing Firm Characteristics or Lower Propensity to Pay?, "Journal of Financial Economics", Vol. 60, No. 1/2001, http://dx.doi.org/10.1016/s0304-405x(01)00038-1.

Ferris S.P., Sen N., Pei Yui H., Are Fewer Firms Paying More Dividends?, "Journal of Multinational Financial Management”, Vol. 16, No. 4/2006, http://dx.doi. org/10.1016/j.mulfin.2005.08.002.

Grullon G., Ikenberry D.L., What Do We Know About Stock Repurchase?, "Journal of Applied Corporate Finance", Vol. 13, No. 1/2000, http://dx.doi. org/10.1111/j.1745-6622.2000.tb00040.x.

Guay W., Harford J., The Cash-flow permanence and information content of dividend increases versus repurchases, "Journal of Financial Economics, Vol. 57, No. 3/2000, http://dx.doi.org/10.1016/s0304-405x(00)00062-3.

Hazlitt H., Inflacja, Wróg publiczny nr 1, Fijorr Publishing, Warszawa 2007.

Horbaczewska B., Wyptaty dla akcjonariuszy a wycena akcji na rynku kapitatowym, CeDeWu, Warszawa 2012.

Jabłoński B., Kuczowic J., The Issue of Dividend Policies of Companies Listed on Warsaw Stock Exchange - Results of the Research, [in:] O. Deev, V. Kajurová, J. Krajiček (eds.), European Financial Systems 2014, Proceedings of the 11 ${ }^{\text {th }}$ International Scientific Conference, Brno 2014.

Jagannathan M., Stephens C.P., Weisbach M.S., Financial Flexibility and The Choice between Dividends and Stock Repurchases, "Journal of Financial Economics", Vol. 57, No. 3/2000, http://dx.doi.org/10.1016/s0304-405x(00)00061-1.

Kowerski M. Ekonomiczne uwarunkowania decyzji o wyptatach dywidend przez spótki publiczne, Konsorcjum Akademickie, Kraków 2011. 
Lintner J., Distribution of Incomes of Corporations Among Dividends, Retained Earnings, and Taxes, "The American Economic Review", Vol. 46, No. 2/1956.

Sierpińska M., Polityka dywidend w spótkach kapitatowych, PWN, Warszawa-Kraków 1999.

Skousen M., Struktura produkcji. Gietda, kapitat, konsumpcja, Fijorr Publishing, Warszawa 2011.

Słoński T., Analiza wptywu wspomaganego dtugiem wykupu akcji (LBO) na wartość spótki, Wydawnictwo Uniwersytetu Ekonomicznego we Wrocławiu, Wrocław 2012.

Szablewski A., Zarzadzanie wartościa firmy. Istota i kierunki erwolucji, [in:] A. Szablewski (ed.), Strategie wzrostu wartości frmy. Studium przypadków, Poltext, Warszawa 2000.

Szablewski A., Tuzimek R., Wycena i zarzqdzanie wartościa firmy, Poltext, Warszawa 2006.

Szczepankowski P.J., Finanse przedsiębiorstwa. Teoria i praktyka, Wydawnictwo WSPiZ, Warszawa 1999.

Tuzimek R., Decyzje finansowe w spótkach gietdowych a wartość akcji, Szkoła Główna Handlowa. Oficyna Wydawnicza, Warszawa 2013.

von Eije J.H., Megginson W.L, Dividends and Share Repurchases in the European Union, "Journal of Financial Economics", Vol. 89, No. 2/2008, http://dx.doi. org/10.1016/j.jineco.2007.11.002.

von Eije J.H., Megginson W.L., Dividend Policy in the European Union, "SSRN Electronic Journal”, Vol. 2006, http://dx.doi.org/10.2139/ssrn.900749.

Wrońska E.M., Polityka dywidend, [in:] P. Karpuś, (ed.), Zarządzanie finansami przedsiębiorstw, Wydawnictwo Uniwersytetu Marii Curie-Skłodowskiej, Lublin 2006. 
